Tarih Kültür ve Sanat Araştırmaları Dergisi

Revue des Recherches en Histoire Culture et Art

مجلة البحوث التاريخية والثقافية والفنية
Vol. 6, No. 1, February 2017

Copyright (C) Karabuk University

http://kutaksam.karabuk.edu.tr

\title{
DOI: 10.7596/taksad.v6i1.698
}

Citation: Forouzani, F., Badr, N., Gorji, M., \& Haghighi, S. (2017). The Role of Language in Processing Various Characters in Bahram Beyzai’s Play: One Thousand and First Night. Journal of History Culture and Art Research, 6(1), 8-21. doi:http://dx.doi.org/10.7596/taksad.v6i1.698

\section{The Role of Language in Processing Various Characters in Bahram Beyzai's Play: One Thousand and First Night}

\section{Farzaneh Forouzani ${ }^{* 1}$, Narges Mohammadi Badr², Mostafa Gorji ${ }^{3}$, Shahin Haghighi ${ }^{4}$}

\begin{abstract}
Language is one of the main components of narrative (both short story and play), the significance of which is irrefutable in narrative literature. Since most events occur within and through language in drama, studying elements of language is quite effective in the analysis of the discourse of characters. Characters communicate and bond with each other through language in a play; thus; the present study aims at the analysis and critical reading of Bahram Beyzai's One Thousand and First Night, as one of the leading playwrights of Iran, in following realms: discourse system and structure of the play, it's variety and tasks, features and functions, and characterization techniques which are realized through language. To do so, the present study scrutinizes the characters of the play in terms of speech and language usage and the effect of language on characterization and the flourishment of personae. Manfred Pfister's Theory and Analysis of Drama has been applied as the main theoretical tools for studying various functions of language, such as referential function, expressive, rhetorical, speech-maker, meta-linguistic, and poetic.
\end{abstract}

Keywords: Play, Playwrights of Iran, Beyzai, Role of language, Drama, Characterization.

\footnotetext{
${ }^{1}$ Corresponding Author, PhD Student of Persian Language and Literature, Payame Noor University of Tehran, Tehran, Iran. Email: farzaneh_foroozani@yahoo.com

2 Assistant Professor, Department of Persian Language and Literature, Payame Noor University of Tehran, Tehran, Iran. Email: badr@pnu.ac.ir

3 Professor, Persian Language and Literature, Department of Persian Language and Literature, Payame Noor University of Tehran, Tehran, Iran. Email: gorjim111@yahoo.com

4 Assistant Professor, Department of Persian Language and Literature, University of Jahrom, Jahrom, Iran. Email: shahin.haghighi@yahoo.com
} 


\section{Introduction}

Language is one of the main components of narrative (both short story and play), the significance of which is irrefutable in narrative literature. The concept of language has enjoyed several definitions; "language is a set of signs or indicative signifiers used consciously by human beings to induce an idea, a command, or information from one perception to another" (Khanlari, 2003: 5). Any argument within the realm of concepts is totally dependent on language. Pragmatic scrutiny of language involves inevitable interpretation of what people mean in a certain context and necessitate investigating how speakers organize their speech with regard to the audience, place, time, and circumstances (Yule, 2013: 11). No communication behavior is as comprehensive and effective and no communication phenomenon is so deeply associated as verbal relationship in human life. This association is so deep that psychologists believe that language has the potential of revolutionizing human beings (Miller, 1989: 7). Since most events occur within and through language in drama, studying elements of language is quite effective in the analysis of the discourse of characters. Theatre characters interact with each other through language and the bond between character and language, as a phenomenon, is inextricable, especially in drama where, apart from descriptions and stage actions, character's usage of language and speech is the sole basis for constructing a through image of them.

Bahram Beyzai is one of the most influential figures in the realm of dramatic literature in Iran; along with Akbar Radi and Gholam-Hossein Sa'edi, he forms the triangle of Iran's dramatic literature (Shahbazi and Kian Afraz, 2008: 599). The present study aims at analyze One thousand and First Night in terms of characterization (protagonist, antagonist, satellite characters) through language. A study of Beyzai works has shown his significant concentration on the power of language; not only does he apply language as a super-structure with several functions, such as contributing to form, transferring data, advancing the story, creating rhythms, and trimming aesthetic issues, but also language becomes an umbrella entity to integrate certain historical, political, and cultural issues of Iran (Mahmudi Bakhtiari, 2009: 15). Beyzai's method in most his works which root in history, myth, and legend, is not addressing the core of the story and part-to-part analysis of the components of narrative; rather, employing the core of the story founding the play on the main character, and introducing new characters in a total sum is his main technique. In terms of these three episodes, it can be said that "Anahita", the goddess of fertility and growth, which can have the same function as "A Thousand and One Nights' Scheherazade, is the main foundation for characterization of figures who play key role in these three episodes. From the viewpoint of the author, the whole story of $A$ Thousand and One Nights is about fertility, prosperity, and happiness and Scheherazade, Shahrnaz (Jamshid's daughter and Zahhak's wife), and Roxanna symbolize Anahita in these three episodes (Mostofi, 2002: 2). Relying on researches he has conducted on the theatre of the Orient and Iran, Beyzai extracts the truth hidden in Oriental thought with great subtlety from the heart of history and myth (Bagheri, 2004: 20-21). In order to attain necessary infrastructure for the flourishment of the present study, the speech system of the play and its variety and tasks, the language, features, and functions have been categorized and characterization techniques have been examined.

\section{Literature Review}

Based on conducted researches, only two studies have been found on the role of language in Beyzai's composition; Dr. Behrooz Mahmudi Bakhtiari and Mahsakurd's An Approach to Bahram Beyzai's Dramatic Language presents a general examination of Beyzai's works and analyzes stylistic aspects of the manipulation of language; the other one is Iraj Kaleh Jahi's 
thesis, entitled Archaic language in Bahram Beyzai's Works, with Focus on Four of His Plays, Death of Yazdgerd, Arash, Azhdahak, and Karname-ye Bandar Bidakhsh, which presents an in-depth analysis of the archaic language of the plays.

\section{Research Questions}

- How do protagonists and antagonists of One Thousand and First Night express themselves through language and speech?

- Is the language of each character in proportion to his personality, role, place, space, and his impact on the progression of the story?

- To what extent is author's personality visible in what character do and say?

\section{How language works in drama}

The original form of the play takes shape through the dialogue between characters; thus, speech is the core of drama, a channel which allows actors to bond and establish relationship. However, it is not the sole factor for the successful flourishment of a play. According to Michel Winy, ancient drama enjoyed a sort of philosophical dialogue which had no common point with theatrical dialogues and speeches; being more alike in comparison to the discourse of media is the main reason for using such speech to express philosophical ideas (1998:4). The speech system of drama can be classified into two groups of dialogue and monologue.

Various dramatic dialogues (where two or more people are involved) include the following categories:

Repartee

Dialogue between two characters is not often a balanced exchange; the presence of some characters in a play is to foreground the amazing repartee of coral character and provide the opportunity and space of speech for him.

\section{Stichomythia}

A piece of dialogue with high pace, short answers of participating characters, and successive give and takes of speech. This quick question and answer emerges at the climax of a dialogue and reflects the intensity of conflict.

\section{Polylogue}

Polylogue is a dialogue among several characters; several characters talk together simultaneously, respond to questions, and their voices interweave. Depending on the intention and plan of the playwright, such a dialogue might either turn into a chorus or different voices fade in each other (Winy, 1998: 34-47).

\section{Irrelevance in dialogue}

According to McKay's interpretation, dialogue in implemented in order to create, show, or change communication and irrelevance of dialogue is not a conventional phenomenon in the speech system of the play (2010: 256). Mutual understanding is the basis of a two-way exchange of information; if characters do not understand each other (even if they curse), they 
won't be able to respond properly; thus, playwrights show the communication among characters through language and the creation of specific speeches (Winy, 1998: 34-47).

\section{Properties of the language of drama}

Seeger believes that the playwright must opt for a middle ground method between conversational speech and literary style of writing; this method should cover the differences as well. The language of drama is not expected to copy and show the vulgar and banal realities of everyday life; rather, it should turn those realities into dramatic dialogues. Such dramatic dialogues are stylized; pseudo-poetic, and unrealistic elements the language of which is different from ordinary speech; reading such dialogues reveals the thoughts and motivations of characters acting in the play. This dialogue should only be in a place of artifacts and offer a simple sense of reality (Seeger, 2009: 202-219).

\section{Multi-functionality of dramatic language}

Language and its function are some of the most prominent criteria to assess the position and personality of the character; for example, the voice, rhetoric, and the practice of character are of crucial significance in the analysis of language (Dowson, 1998: 30). Manfred Pfister, in The Theory and Analysis of Drama, attempts to differentiate the language of drama from other kinds and genres of literature based on a claim of multi-functionality of the language of theatre. Every single dramatic expression conducts several communicative functions simultaneously; however, one aspect might dominate the final mission. Pfister categorizes multi-functions of dramatic language as the followings:

\section{Referential function}

This function implies that the spoken word in drama functions as a means of representing objects like humans, things, or events that are talked about. These specific elements of design are presented in completely spoken form in the narrative, because they cannot be performed on the stage due to either economic or technical issues. This function enables the playwright to transform information to the audience with both internal and external levels of the play.

\section{Expressive function}

As one of the most important characterization in drama, this technique is intertwined with the speakers of a dialogue. This technique reveals the interests, behaviors, and the style of the speech of the character. Expressive function of language has central function if the purpose of the speech is the revelation of the thoughts of a character. The tendency of the speaker to share his thoughts and decision is the basis of expressive function of language.

\section{The appellative function}

The appellative function is clearly dependent on dialogue and its significance and function varies according to the extent of the presence of interlocutor in the dialogue; the harder the speaker tries to affect the mind of audience and the more vehemently the speaker respond to the feedbacks of speakers, the stronger this function gets. Order or command is an obvious form of exercising power on the stage of a play which prerequisites a particular sort of communication between partners of a dialogue. This function is strengthened through repeated pleading, addressing the dialogue partner by name, and trying to provide frequent reasons for influencing the opposite side. 


\section{The phatic function}

The phatic function of language creates and maintains the relation between speaker and listener. This function analyzes the creation and enhancement of contact and dialogue among characters. The difference between appellative and phatic function is that the sole essence of established dialogue is much more important than it's impacts and influences in this method.

\section{Meta-lingual function}

This function is related with the verbal code. In this case, itself of the verbal code becomes important as its examples can be seen when the meeting of two dialogue partners results in a contrast between vulgar language and a more differentiated mode of expression, or even misunderstanding. Thus, they speak metalingually with and about their own language. In order to foreground metalingual function the clarity of verbal code is not required; a simple reference to the code is enough.

\section{Poetic function}

This function of language appears during interaction between the internal communication system of the dramatic personae and the external communication system of the audience. It only emerges when the message attracts the attention of the audience to itself. For example, the language of a character might become totally poetic in one part of the play; however, this poetic mode of expression belongs to the playwright rather than personae. Audience understands this poetic quality but other characters don't. The playwright prefers to choose certain poetic expression for a demarcated part of play in order to create desired emotional tone and effects. Thus, he applies character's stream of consciousness in a poetic form to motivate character's sympathy (Pfister, 2008: 142-167).

\section{Categorizing personae by their role in the narrative}

Hero

Hero is the main character and the center of the actions of the play. The concept of hero has changed drastically over time (Ahmadzede 2012: 35) and it no longer identified as a godlike figure it used to be in the past. Nowadays, writers suspend their lifelike characters between realism and romanticism instead of creating exceptional figures. The dignity of the hero is another factor which makes him popular and superior to other characters and makes audiences like him (Scott Card, 2008: 169).

\section{Anti-hero (evil character)}

This character can be either central or marginal and is in conflict with the hero; normally, such a character is an evil figure because of the function he must fulfill in the course of narrative; i.e. struggling against the good character who occupies the central role of the hero in the story (Seeger, 2009: 184).

\section{Supporting, complimentary characters}

These figures complete the character of hero and rotate around him as satellites and they provide the opportunity for the revelation of different aspects of the hero in different times, places, and relationships (ibid: 186). 
This part will present a study of the above-mentioned theoretical arguments in Bahram Beyzai's One Thousand and First Night.

\section{The drama of One Thousand and First Night}

This play consists of three episodes which can be read critically as a combination of two myths of Zahhak and One Thousand One Night.

\section{The first episode of One Thousand and First Night}

Shahrnaz and her sister, Arnavaz, hope for the decline and fall of Zahhak on the one thousand and first night of his frightening monarchy. They had come one thousand and one night ago willingly to Zahhak's castle to entertain him and make his snakes asleep by telling him story each night and set Jamshid free, one of two young boys who is expected to be sacrificed. One thousand and first story is the story of one thousand and one youth who, led by Fereidoon, have revolted to overthrow the monarchy of Zahhak (Beyzai, 2006: 7-37). Shahrnaz is the hero of narrative in this episode and Zahhak is the anti-hero. Arnavaz, Jamshid's other daughter, is a complimentary character whose presence helps Shahrnaz as the heroine of the story.

Investigating the relationship of the heroine (Shahrnaz) with other dramatis personae (antihero and supporting character) through dialogue.

\section{Repartee}

Shahrnaz presents a high degree of repartee and awareness of different aspect of his thought; her quick responses demonstrate her intelligence and ability to make proper decisions in face of Zahhak. "Zahhak: my victory against rebels has been written in the mountains! Shahrnaz: have you gained victory over yourself, too?! Zahhak: keep quiet! I am Zahhak! Shahrnaz: this is what I said; the world would be different if you were Jamshid” (ibid: 21).

\section{Stichomythic}

This episode opens with a stichomythia among three main characters; the opening speech helps audience get familiar with the personae to some extent; "Zahhak: are you real? Shahrnaz and Arnavaz, or just in my dream?! Shahrnaz: we are not in your dream Zahhak; you dream in your own sleep but you don't let us have piece! Zahhak: why are you awake! Arnavaz (with a faked yawn): sleep has long left our eyes” (ibid: 7).

\section{Shahrnaz's linguistic characteristics}

\section{The dominance of appellative function in is Shahrnaz's language}

In addition to explicit, profound, and analytical self-expression, Shahrnaz addresses the antihero directly by his name; she includes her thoughts and ideas to Zahhak in this way. She speaks of inside world with confidence and her speech is full of logic and reason and these make audience like her and sympathize with her, because both the type and content of the utterance seem reasonable and irresistible. This function of language is totally in harmony with Shahrnaz's role as a leader and commander. "Shahrnaz: I have conducted no story, Zahhak. The story is made and transmitted by those people whose brains are fed to your snakes! Zahhak: didn’t I defeat enemies and make them kneel in front of me?! Shahrnaz: you 
have defeated all but the devil inside you which is devouring every inch of humanity you might have” (ibid: 10-11).

\section{Poetic function in Shahrnaz's language}

Most of Shahrnaz's sentences are poetically gifted: her statements can function like poems and make sense independently outside of the space of lay; "we are not your hallucination Zahhak; you sleep but don't let us have piece” (ibid: 7); "the story came up to the back of lip and fought with the teeth because there was no ear ready to hear what was willing to come out” (ibid: 9). “Open the doors Arnavaz; the sleep of streams is now broken” (ibid: 37).

\section{Expressive function of Shahrnaz's language}

Through the language of Shahrnaz, the playwright provides sporadic interpretations on different actions or speeches of characters; the frequency of such interpretation is so high that a great extent of the knowledge of the audience about characters originates from Shahrnaz's utterances. "People tell that Jamshid was not in the tree you cut in two! Jamshid had reacted much sooner than the agility of your saws and he had gone to the other world to judge the dead, or maybe you one day”. This part anticipates Jamshid's death prior to its occurrence.

Characters within the context of the narrative, and audiences, outside the world of narrative, are involved within the progression of events through Shahrnaz's artistic descriptions; for example, when Shahrnaz describes the details of the murder of the youth, anxiety and stress of people, and the cruelties of Zahhak's monarchy, the readers feel direct link with gloomy atmosphere of the narrative and when she describes the advent of the army of Fereidoon, riding a boar, the audience totally feel the apprehension of Zahhak government (ibid: 37).

\section{The language of Zahhak (the anti-hero)}

\section{Expressive function of Zahhak's language}

This function has the highest frequency in Zahhak's speech; he constantly attempts at maintaining his dialogues with Jamshid's daughters and they react to and challenge what she says. Like Shahrnaz, Zahhak is a stubborn and adamant repartee user who talks heedlessly, does not withdraw against what Shahrnaz and Arnavaz say, and ridicules these two sisters. "Arnavaz: you could very easily accept defeat by saying that my stories don't make sense any longer! Zahhak: stop talking and don’t give up” (ibid: 9).

\section{Simultaneous dominance of appellative and expressive functions in Zahhak’s language}

\section{a. Self-referentiality:}

Zahhak confesses his misery and weakness against Shahrnaz and Arnavaz's clever remarks by talking and referring to himself; "Zahhak: hey you, Zahhak! Have patience and hold your grounds, for you must hear out everything” (ibid: 13).

\section{b. Seeking excellence and thirst for power:}

Zahhak frequently expresses his psychotic thirst of power in different occasions: he uses his language to foreground his victories and excellence over Jamshid while talking to Jamshid's daughter; "what?! the story of my sovereignty? It would definitely attract my attention, for I have experienced every single bit of what you are going to tell me” (ibid: 9). 
c. Humiliating Jamshid’s daughters through language

Zahhak humiliates the hero of the story in order to prove his superior position both as a man and a king in order to strengthen his position; "Zahhak (laughing)! Women are idiot and illogical even if she is Jamshid’s daughter” (ibid: 17).

Analysis of the language of complimentary character (Arnavaz)

Arnavaz is Jamshid's second daughter who has been brought to Zahhak's court along with Shahrnaz. The playwright employs her in order to move the events of the story forward.

\section{Referential function of Arnavaz's language}

It seems that referential function is the most dominant form of language form of language usage in Arnavaz's speech, because what she says implies the author's intention and plan to provide descriptions; she is a channel for the establishment of contact between the source and final destination, presenting opportunity for the description of parts which are not needed or cannot be performed on the stage. "Arnavaz: listen and know that the devil first came to him as a saucer and asked him to kill his father; he killed him and took his throne. Then, the devil came to Zahhak as a cook and brought him food so delicious that he wanted to give him bonus and gifts; instead of bonus, the devil asked Zahhak to let him kiss his shoulders. He agreed and the devil kissed his shoulder and two snakes sprung up where he had kissed Zahhak’s shoulders” (ibid: 32-33).

\section{Expressive function of Arnavaz's language}

What Arnavaz, as the complementary character of this episode of the play, says has expressive function in Shahrnaz's conscience as the heroine of the play. What Arnavaz adds to Shahrnaz's utterances portrays her thoughts and desire in a deconstructive sort of way and draws audience's attention to the essence of their action. "Shahrnaz: I told my sister that Zahhak has usurped the kingdom my father and rules people with great cruelty and heartlessness and eats the brains of the youth! Arnavaz: what a pity for those young people who were fed to the snakes in order to destroy Iran! Shahrnaz: yes, what a pity! Arnavaz: up to when this crying and moaning must continue in private?” (ibid: 13).

\section{Summary of the second episode of One Thousand and First Night}

Poorfar Khan, along with his wife, Khoorzad, and his sister, Mahak, has come from Ray to complain of the oppression of the governor of that city to the supreme judge; he translates $A$ Thousand Myths from Pahlavi to Arabic as suggested by Sharif, the chief businessman of Baghdad, but the Arab enslave and torture him. They change the color of the book into an Arabic dictionary, change the name of the book, and, along with other trophies, send it to the treasury of the caliph; Poorfar Khan's sister and wife kill themselves before becoming slaves to Arabs (Beyzai, 2006: 39-77).

\section{Investigating the language of Khoorzad as the heroine of the narrative}

The dominance of expressive and appellative functions in the language of Khoorzad

As an informed critical, and open-minded lady, Khoorzad, in addition to expressing her real world, addresses the audience to share with them what goes on in her mind and show her strength. By expressing her inner miseries and throes, she actually bemoans the difficulties of 
a nation (Ray, Iran) who has had to surrender to the dominance of Arabs; thus, none of her obsessions are thoroughly personal. She reflects and represents the voice of a nation who, based on Khoorzad's expressive function of language, is under cruelty. The initial combination of these two functions seems to have the potential of affecting Arabs at first; however, their dominance is so monolithic that actually, despite clear resilience, destroys his woman. In most of what she says, she presents self-expressions in order to reveal herself to the audience. The misery of people, national figures, books, and science which have fallen to the foots of ignorant are of prominent significance in her self-expressions, expressions which are mostly what Beyzai intends to say. Except for Poorfar Khan, a great extent of the knowledge of audience of what goes on the story roots in Khoorzad's speeches and dialogues; for example, her interpretation of the book "A thousand Myth", which familiarize the audience with the essence of the book, is a valuable source of knowledge for the audience (ibid: 45). "Khoorzad (picks up the book): did you notice that they kill the storyteller to sell the story expensive" (ibid: 72). What she says is actually what the playwright thinks; thus, Khoorzad functions as a channel to transmit Beyzai's different readings and interpretations.

\section{Poetic function of Khoorzad's language}

\section{a. Poetic and aphoristic properties of Khoorzad's language}

Khoorzad frequently talks to inanimate objects in a poetic language. In these cases, what she says is like a bereavement poem in which she either tries to attract the sympathy of some body or criticize the bad omen of the world; "oh, you flute, worthless object! You were no more than a small thing by the river of Forat, like all those reeds which are burnt and scorched in front of sun. People made you what they were, either a spear or a pen” (ibid: 71).

\section{b. Arabic proficiency of Khoorzad}

Although Khoorzad's language is affected by the historical, archaic style of the narrative, which is itself an inseparable property of Beyzai's works, she speaks with high mastery of Arabic language while talking to Sharif of Baghdad to pay respect to Sharif (ibid: 41); although she starts her dialogue in Arabic, she continues in Farsi when Sharif leaves the stage; this is another property of Beyzai's unique style.

\section{The analysis of the language of Sharif, the most prominent businessman of Baghdad, (anti-hero)}

Sharif, the most prominent businessman of Baghdad, (anti-hero) is a character whose speech shed light on the character of the other anti-hero, caliph; he, actually, is the deputy of caliph.

\section{Appellative function of Sharif's language}

To torture Khoorzad and Mahak, Sharif constantly accuses the Ajam of blasphemy and values his being an Arab; "I, humble human being, have passed sometime in the land of the pagan, Ray and its surroundings” (ibid: 47).

He constantly interprets the names and nouns Khoorzad and Mahak use in order to show the superiority of Arabic language in comparison to Farsi; he, even, translates their names into Arabic to prove the superiority of Arabic. He, even, starts coining words; this exaggerative strategy is used by the playwright to provoke audience's hatred towards this character; "Mahak: this message is from Poorfar Khan! Sharif (with a warning tone): his name is translated as the son of monkey! Mahak: what about the son of Mazdak the mentor?! Sharif: 
his name is translated as the son of vulture writer! Mahak: what about the name of my beloved wife, Khoorzad?! Sharif: call her the daughter of the sun! Mahak: and my sister, Mahak?! Sharif: call her the curve of the moon” (ibid: 41-42).

\section{Poorfar Khan's language as the second hero of the narrative}

Poorfar Khan is considered the second hero of the narrative because Beyzai, due to the respect he feels for women, gives the central role to women or, generally, the spirit of women hood in his works. From another perspective, Poorfar Khan can be associated with the playwright himself who narrates the crucial role of women in changing and enhancing the world. The narrative and history of A Thousand Myths is deeply entangled with this character.

\section{The expressive function of Poorfar Khan's language}

Repeated interpretations of Scheherazade and the story of Zahhak are indicative of his expressive language. It can be claimed that the playwright has hidden himself behind this character and transmits his historical and mythological knowledge to the audience. Consequently, most of his dialogues turn out to be didactic due to the high volume of information embedded in them. Beyzai's anti-mythical and unique readings are quite clear in interpretations Poorfar Khan provides for certain events and mythical figures. Thus, sometimes, what he says seems too huge for the stage. For example, he intends to distinguish the era of myth from the age of reason under torture and this is, temporally speaking, quite a more recent approach in terms of mythology; his meticulous, precise interpretations of historical and mythological events and figures indicate his expressive function of language (ibid: 67).

\section{The third episode of One Thousand and First Night}

This play provides a critical reading of Zahhak's story which portrays the contrast between the awareness of women and the ignorance of men.

\section{The summary of the third episode of One Thousand and First Night}

Roshanak is the heroine of this part of the narrative; she is an educated woman who revolts against the illiteracy of her husband, Mir Khan, who closed down Roshanak's mother's school in the past. Roshanak's mother set herself on fire as protest against the closing down of her school. Years later, Roshanak marries Mir Khan because she believes that she can change him and make him a respectable figure. She reads A Thousand and One Night in privacy, something which is considered a huge disgrace in the eyes of the elderly of the society; then, she pretends that this act has brought her much close to death and that she is actually dying. In Roshanak and Mir Khan's stichomythia, her logical and intellectual arguments reveal the meaninglessness of Mir Khan's arguments. Finally, Roshanak goes back to her teaching occupation, her first student being her husband, Mir Khan (Beyzai, 2006: 79-107).

\section{Analysis of Roshanak's language as the heroine of this part of narrative}

Roshanak retells the story of her mother's self-immolation, as a secondary narrative, for Roxanne. In doing so, she changes the story the way she likes; "May her soul rest in peace! She was my teacher and, despite being young, she conducted the school in such a way that no elderly mentor could take her success. A woman with a school which could endanger the future life of baby girls was a disaster for them" (ibid: 84). The feminist tendency of the narrator is quite clear here and Roshanak interprets and changes the story in proportion to the 
objectives she has in mind; "Mir Khan: sooner or later, death would go to a woman who reads Scheherazade! Roshanak: this death might be actually what the wise wish for the educated lady" (ibid: 164).

Roshanak's repartee shows her speed and agility of mind in providing suitable answers for the addressee. "Roxanne: isn't faking death difficult?! Roshanak: not as difficult as death itself” (ibid: 82). "Roxanne: I swear by the word you have taught me that you are not like what you used to be! Roshanak: I always wanted to be like me" (ibid: 86). "Mir Khan: there are numerous about prostitute women! Roshanak: women who have been made prostitute by men” (ibid: 105). Roshanak's final speech shows the similarity of her character to Scheherazade; it also reveals the importance of the role of women in this play.

\section{Poetic function of Roshanak’s language}

\section{a. Poetic and aphoristic properties}

Most of Roshanak's sentences are aphorisms; this shows her great wisdom and intellect; "which man has not set a woman on fire?" (ibid: 86). "Isn't the verdict of the wise a mask to conceal your real self?” (ibid: 100). "When wisdom emerges in a woman, people call it deceit and when deceit emerges in men, people call it wisdom” (ibid: 105). The style of the speech of characters of this episode is mostly archaic, which belonged to Qajar period. However, subtlety, rhythm, and wise aphorisms of Roshanak are totally in harmony with her teacher character; but, they are not compatible with her historical, intellectual, and cultural era. Her dialogues are excellent manifestations of Beyzai's mastery of language which, technically speaking, reveals some traces of the personality of the playwright in the play.

\section{b. Irony in Roshanak’s language}

Irony is frequently used in Roshanak's utterances and she indirectly protests against Mir Khan; in response to Mir Khan's expression of affection, when he states that he has given one coin for each day of his wife's illness to a beggar and that he is ready to give a thousand coin providing the improvement of the health of his wife, she ironically states that "sorry for all the money you gave to the beggar, but my departure is not a choice of my own. Instead, I promise to die much sooner than your spending 100 coins” (ibid: 92).

\section{c. Anachronism of Roshanak’s utterances}

Most of what Roshanak says is much more significant than her historical, cultural, and educated character as a literate woman. Most of her dialogues belong to a demarcated group of contemporary educated women and this shows the presence of the author behind the mask of this character as a woman belonging to an occupation Beyzai appreciates much, teachers. Different examples of such open-minded, intellectual dialogues, which show the playwright's remarkable mastery of language are dispersed in the text. For example, Roshanak creates an analogy between her children and her thoughts where the children are alive as long as their mother is alive with knowledge and reading; "Roshanak: my children are my thoughts! Mir Khan (angry): I wish they were born dead; we don't need thought because we have religion and tradition and guidance. I wanted children of my own blood! Roshanak: thoughtless children you mean?! Mir Khan: Alive children like me! Roshanak: you will have an alive child, equipped with thought and wisdom...no.... a dead mother cannot give birth to an alive creature” (ibid: 99). 


\section{Portraying Roshank's wisdom through integrating dialectic structure of dialogue}

Roshanak uses a dialectic structure in her dialogue with Mir Khan and she gradually makes him see the meaninglessness of his arguments. Logical structure, coherence, and the progression of Roshanak's utterances are in such a way that they reveal Mir Khan weaknesses one by one; consequently, he discovers the value of knowledge and literacy and begs Roshanak to teach him how to read and write. The ability to overcome such verbal design signifies the wisdom of this lady who has a deep connection with knowledge and reading.

\section{Analyzing the language of Mir Khan, the anti-hero of this episode}

\section{Poetic and expressive functions of Mir Khan's utterances}

Mir Khan, an illiterate man who is deeply against the teaching and reading of his wife, Roshanak, is the anti-hero of this episode of the play; he is the person who caused the death of Roshanak's mother by closing her school down, and this made Roshanak determined to do her best to change this man. Although the context of the story reveals Mir Khan to be an outdated man, some of his speeches are totally poetic and we see a respectable man whose expressive speeches make Roshanak doubtful; he tries to convince Roshanak to give up reading through an expressive style of speech; "Mir Kahn: what a pity that destiny does not negotiate, discount, delay, thread, or obey! Why is she dead and you are still alive? I hate myself! Damn with you because you are happy with my misery” (ibid: 88).

"Mir Khan: I swear to God that I won’t marry or love after you! I close my eyes and hold my tongue; my heart is but a deserted place when you have left it” (ibid: 95).

"Mir Khan: I give up sword because you gained victory unarmed! We will clean your school tomorrow and I'm sure you will make a very good teacher who teaches the poor without expecting anything. Let happiness in the house because death has left here” (ibid: 107).

\section{Conclusion}

The first episodes of Beyzai's One Thousand and First Night are dominated by myth and legend and a hybrid genre (a mixture of epic, historical, social, and family genres). Where major preoccupations of contemporary society, such as feminism, are integrated into a world of myth and legend; it attempts to presents a new creation of the narrative of A Thousand and One Nights. The portrayal of characters is totally in harmony with both the genre of the work and the school of the thought of the playwright; the majority of the properties of characters emerge under the gradual flourishment of the requirements of the genre. Both the hero, Shahrnaz, and the complimentary character, Arnavaz, are prone to different interpretations and their language, speech, dialogue, and utterance are totally compatible with their position. On the other hand, the language and speech of the anti-hero is totally in harmony with the historical and mythological texture of the narrative of the first episode; actually, how the antihero speaks determines his social position.

The narrative of the second episode of One Thousand and First Night originates from the context, characterization, language, and other elements of a historical drama. Beyzai has present different interpretations under the influence of nationalistic, feministic, political, and social tendencies. Although Khoorzad has functioned very successfully as the heroin of this narrative, Beyzai's presence is totally clear behind characters and their ideas in different occasions; thus, this incompatibility between the extent of the knowledge of the heroin and 
her historical context creates this orientation in the audience and makes accepting this idealism of the character a very difficult job. The grandeur of this woman and the futility of her opposing characters (Arab Men) is so exaggerated that the audience feels ethnic and racist prejudice in different occasions. On the other hand, Poorfar Khan the complimentary character of this episode, is involved in this act of exaggeration and functions as a channel for the transmission of Beyzai's ideas. Anti-mythical and novel readings of Beyzai are discernible behind Poorfar Khan's interpretations of mythical characters and events.

The third episode of One Thousand and First Night is a social-family comedy where the writer attempts to present a novel framework for the mythical figure of Zahhak and the myth of Scheherazade the storyteller; this phenomenon results in the creation of multi-dimensional characters. Within this new context, the negative, Zahhak aspect of the male character of the narrative is his ignorance and illiteracy and the god like aspect of the female character is her knowledge and ability to read which is totally evident in the speech of both characters; ideally this episode end with the victory of feminine wisdom and knowledge.

The irrefutable presence of the playwright behind the character of Roshanak and allocating dialogues to her which are much more beyond his capacity sacrifices the complexity of this character to the desire of the writer for voice in the narrative; the style of the speech of Mir Khan, the anti-hero of this episode, is also much more beyond the capacity and knowledge of his society; however, he is nothing in comparison to the grandeur of Roshank's personality.

It can be claimed that characterization of the hero and anti-hero within the first episode of One Thousand and First Night is flawless, integrate, and totally harmonious with other parts and components of the narrative. Appellative, expressive, phatic, and poetic functions of language are more evidently discerned in three episodes of One Thousand and First Night; these functions help the playwright to provide more successful characterization.

\section{References}

Ahmadzade, Ali Reza (2012). Dictionary of Theatrical Terms. Tehran: Faraz Pub.

Bagheri, Elham (2004). The Confrontation of Myth and History in Beyzai's works. Tehran: The World of Ideas Pub.

Beyzai, Bahram (2006). One Thousand and First Night. Tehran: Publication of Intellectuals and Women's Studies.

Card, Scott (2008). Characterization and Point of View in Story. Translated by Parisa Khosravi.

Dowson, S. (1997). Drama. Translated by Firooze Mohajer. Tehran: Center Publication.

Khanlari, Parviz (2003). The Rhythm of Persian Poetry. Tehran: Iran's Cultural Foundation Publication. 
Mahmudi, Bakhtiari \& Behrooz (2009). An Approach to Bahram Beyzai's Language of Drama. Thesis.

McCarthy, Robert (2010). Story: Structure, s-Style, and Principles of Writing Plays. Translated by Mohammad GozarAbadi. Tehran: Hermes Publications.

Miller, Gerald (1989). Verbal Communication (Rhetoric Analysis). Translated by Ali Zekavati Gharagozloo. Tehran: Soroosh Publications.

Mostofi, Babak (2002). "Myth, Tragedy, and Current story writing: An Interview with Bahram Beyzai on One Thousand and First Night”. New Rose Journal. pp 7-27.

Pfister, Manfred (2008). The Theory and Analysis of Drama. Translated by Mehdi NasrollahZade. Tehran: Logics Publication.

Seeger, Linda (2009). The Creation of Characters: A Guide to the Formation of Characters in Movies, Television Series, Novels, Short Stories. Translated by Masood Madani. Tehran: Rahrovan Pouyesh Publications.

Shahbazi, Kazem \& Kian, Afraz, Azam (2008). Iran's Theatre in the Passage of Time. Tehran: Afraz Publications.

Winy, Michael (1998). Theatre and its Principle Issues. Trans by Soheila Fattah. Tehran: Semat Publications.

Yule, George (2013). Language Pragmatism. Translated by Mohemmad Ammozade and Manoucher Tavangar. Tehran: Semat Publications. 